JNNP

\title{
Rate of familial amyotrophic lateral sclerosis: a systematic review and meta-analysis
}

Susan Byrne, Cathal Walsh, Catherine Lynch, et al.

J Neurol Neurosurg Psychiatry published online November 3, 2010

doi: 10.1136/jnnp.2010.224501

Updated information and services can be found at:

http://jnnp.bmj.com/content/early/2010/11/03/jnnp.2010.224501.full.html

\section{These include:}

References This article cites 72 articles, 29 of which can be accessed free at: http://jnnp.bmj.com/content/early/2010/11/03/jnnp.2010.224501.full.html\#ref-list-1

$\mathbf{P}<\mathbf{P} \quad$ Published online November 3, 2010 in advance of the print journal.

Email alerting Receive free email alerts when new articles cite this article. Sign up in the service box at the top right corner of the online article.

\section{Notes}

Advance online articles have been peer reviewed and accepted for publication but have not yet appeared in the paper journal (edited, typeset versions may be posted when available prior to final publication). Advance online articles are citable and establish publication priority; they are indexed by PubMed from initial publication. Citations to Advance online articles must include the digital object identifier (DOIs) and date of initial publication.

To request permissions go to:

http://group.bmj.com/group/rights-licensing/permissions

To order reprints go to:

http://journals.bmj.com/cgi/reprintform

To subscribe to BMJ go to:

http://journals.bmj.com/cgi/ep 


\title{
Rate of familial amyotrophic lateral sclerosis: a systematic review and meta-analysis
}

\author{
Susan Byrne, ${ }^{1,3}$ Cathal Walsh, ${ }^{2}$ Catherine Lynch, ${ }^{1}$ Peter Bede, ${ }^{1,3}$ Marwa Elamin, ${ }^{1,3}$ \\ Kevin Kenna, ${ }^{3}$ Russell McLaughlin, ${ }^{3}$ Orla Hardiman ${ }^{1,3}$
}

'Deparment of Neurology, Beaumont Hospital, Dublin, Ireland

${ }^{2}$ Department of Statistics,

Trinity College, Dublin, Ireland

${ }^{3}$ Trinity College, Dublin, Ireland

Correspondence to

Dr S Byrne, Beaumont Hospital, Beaumont Rd, Dublin 9, Ireland; suabyrne@gmail.com

Received 19 July 2010 Revised 14 September 2010 Accepted 19 September 2010

\section{ABSTRACT}

Background The population rate of familial amyotrophic lateral sclerosis (FALS) is frequently reported as $10 \%$. However, a systematic review and meta-analysis of the true population based frequency of FALS has never been performed.

Method A Medline literature review identified all original articles reporting a rate of FALS. Studies were grouped according to the type of data presented and examined for sources of case ascertainment. A systematic review and meta-analysis of reported rates of FALS was then conducted to facilitate comparison between studies and calculate a pooled rate of FALS.

Results 38 papers reported a rate of FALS. Thirty-three papers were included in analysis and the rate of FALS for all studies was $4.6 \%$ (95\% Cl 3.9\% to 5.5\%). Restricting the analysis to prospective population based registry data revealed a rate of $5.1 \%(95 \% \mathrm{Cl} 4.1 \%$ to $6.1 \%)$. The incidence of FALS was lower in southern Europe. There was no correlation between rate of FALS and reported SOD1 mutation rates.

Conclusion The rate of FALS among prospective population based registries is $5.1 \%$ (Cl 4.1 to $6.1 \%)$, and not $10 \%$ as is often stated. Further detailed prospective population based studies of familial ALS are required to confirm this rate.

\section{INTRODUCTION}

Amyotrophic lateral sclerosis (ALS) is a neurodegenerative disease which was first described by Charcot in the mid-nineteenth century. It is predominantly a sporadic disease but a small percentage of cases occur within kindreds. ${ }^{1}$

In 1955, Kurland et al published a case series of 58 patients in which $10 \%$ reported a family history of ALS. ${ }^{2}$ Although subsequent publications have reported varying rates of familial amyotrophic lateral sclerosis (FALS), the figure of 10\% remains as the accepted population frequency of FALS. $^{3-7}$

There is no definitive definition for FALS. It is generally accepted that the presence of ALS in either a first or second degree relative of the index case constitutes the familial form of the disease. Genes known to be associated with FALS include SOD1, TARDP, FUS and ANG. ${ }^{8}$ The frequency of SOD1 mutations has been estimated to account for $10-20 \%$ of all FALS cases. ${ }^{6}$ This estimate is not population based and most studies preferentially recruit patients with familial ALS. ${ }^{9}{ }^{10}$ To date only one population based estimate of SOD1 frequency has been carried out, reporting a rate of $13.6 \% .{ }^{11}$ Estimation of the rates of SOD1 related FALS is also confounded by the occurrence of mutations in up to $5 \%$ of the sporadic population, some of whom represent familial disease with incomplete penetrance. ${ }^{12}$ The population frequency of the other known causative genes within populations has not been established.

We performed a systematic review and metaanalysis of all studies that presented original data reporting a rate of FALS (ie, the proportion of familial cases among all ALS cases, either in a defined population or in a case series). Analysis of the population based frequency of FALS was then undertaken and, where possible, a geographic comparison was made with the frequency of known SOD1 mutations.

\section{METHODS}

Systematic search

A Medline literature search was performed to identify all published studies on FALS, in addition to ALS incidence and prevalence studies from 1966 to October 2009. The MeSH terms 'ALS', 'amyotrophic lateral sclerosis', 'FALS', 'familial amyotrophic lateral sclerosis', 'familial motor neuron(e) disease', 'motor neuron(e) disease', 'MND', 'incidence', 'prevalence' and 'mortality' were used. Additional references were sought from cited articles. Where no information was reported on the rate of FALS in a population based study, the corresponding author was contacted where possible. Unpublished up to date data from the Irish ALS prospective population based register was also used.

\section{Eligibility criteria and data collection}

All studies presenting original data that reported a rate of FALS (ie, the proportion of familial cases within a defined cohort) were included in the systematic review. Only studies that demonstrated complete enrolment, either in the form of population based registry or in sequential case series, were analysed. Studies with non-random enrolment or cohorts enriched for familial disease were not included in analysis.

Studies fulfilling inclusion criteria were grouped together according to the type of data presented: (1) prospective registry based studies that aim to capture all cases within a given geographic region in order to define incidence and prevalence; (2) retrospective studies that attempt to capture all cases in a given geographic region with the aim of estimating incidence and prevalence; (3) prospective cases series; and (4) retrospective case series. 
Table 1 Comparison of the type of study, rate of familial amyotrophic lateral sclerosis, source of case ascertainment and case inclusion criteria for each study

\begin{tabular}{|c|c|c|c|c|c|c|c|}
\hline Country & Years & FALS & Total ALS & $\%$ FALS & Ascertainment & Diagnosis & Comments \\
\hline \multicolumn{8}{|c|}{ Group 1: prospective population based registry } \\
\hline Puglia, Southern Italy & 1998-1999 & 2 & 130 & 1.50 & $A, B, C, D, G, K$ & $\mathrm{Bii}, \mathrm{H}, \mathrm{J}, \mathrm{L}, \mathrm{N}$ & \\
\hline Piemonte, Northern Italy & $1995-2004$ & 53 & 1260 & 4.20 & $A, D, H$ & Bii, N & \\
\hline South-East England & $2002-2006$ & 31 & 472 & 6.60 & $A, B, C, G, J$ & $\mathrm{Bii}, \mathrm{H}$ & \\
\hline Washington, USA & $1990-1994$ & 9 & 174 & 5.20 & $B, G$ & $\mathrm{G}, \mathrm{H}, \mathrm{K}, \mathrm{L}$ & Personal communication with author \\
\hline San Francisco, USA & $1970-1986$ & 52 & 708 & 7.30 & $A, B, C, G, H, L$ & $A, D, H, J, N$ & Only paper to give criteria for familial ALS \\
\hline
\end{tabular}

Group 2: retrospective population based study

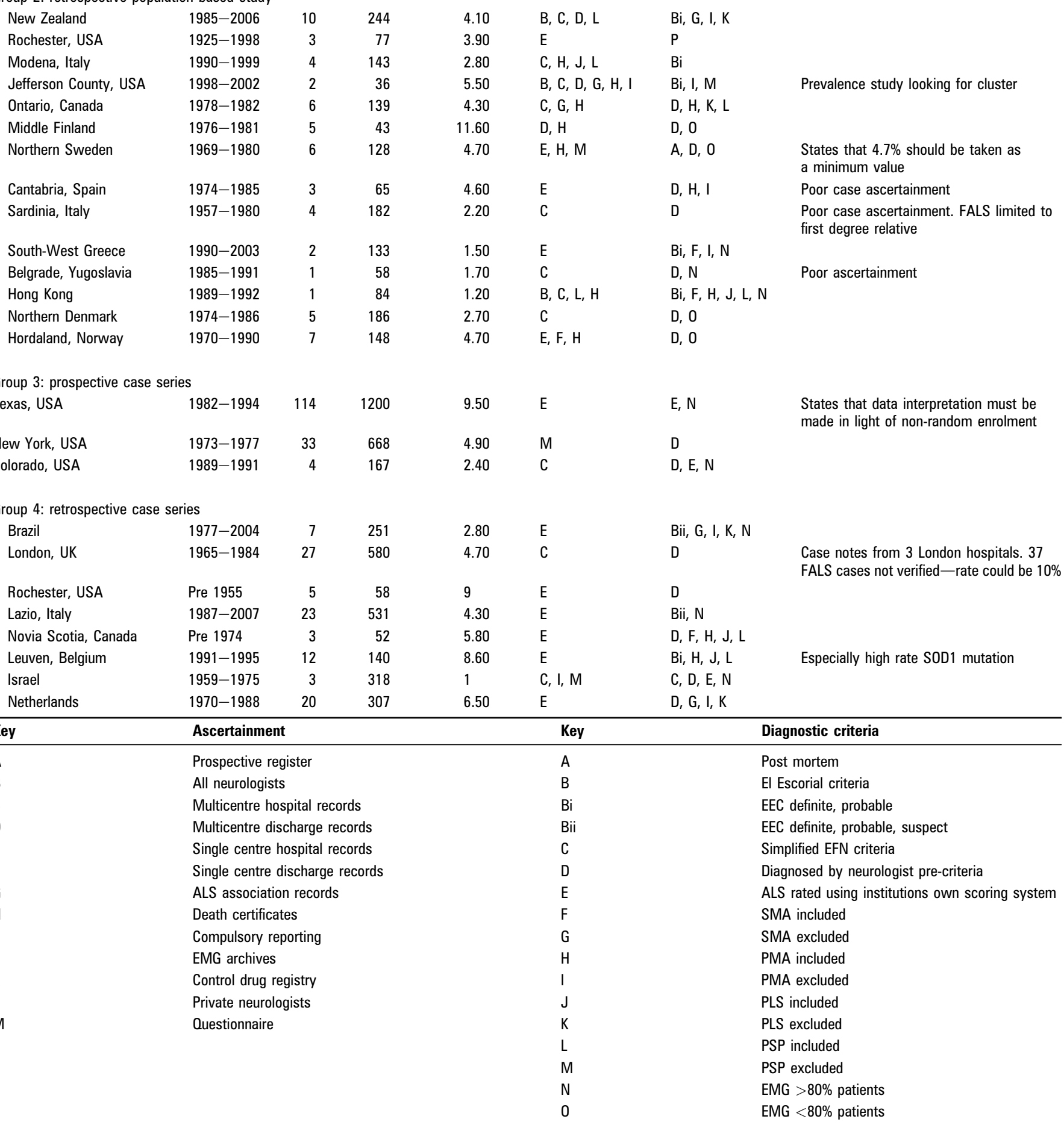




\section{Statistical analysis}

In each study the rate of FALS is reported as the number of familial cases among all cases of ALS. Statistical analysis was carried out to combine proportions using the Meta function of $\mathrm{R}$ (R Development Core Team (2009). R: A language and environment for statistical computing. R Foundation for Statistical Computing, Vienna, Austria. ISBN 3-900051-07-0 http://www. R-project.org/).

The inverse variance method was used to pool proportions. Both fixed and random effects models were estimated and $95 \%$ CIs were calculated.

\section{RESULTS}

\section{Systematic review}

Fifty-four epidemiological studies provided original information on cohorts of patients with ALS. ${ }^{910} 13^{13-66}$ A rate of FALS was reported in 38 of these studies, ${ }^{9} 1013-4663-66$ although in no case was FALS ascertainment the primary objective. Five studies were not included in the analysis. ${ }^{10}$ 63-65 Of these, two were undertaken to genotype mutations in the ALS population. Both studies exhibited enrolment bias. ${ }^{9}{ }^{10}$ Three studies reported data on more than one occasion ${ }^{63-65}$ and therefore only the most recent study was included in the meta-analysis. Reports from geographical areas with high incidence clusters (Guam/Kii Peninsula of Japan) were excluded. ${ }^{66}$

Of the 33 studies analysed, ${ }^{13-46}$ eight reported incidence data from prospective population based registers ${ }^{13-21} ; 14$ reported retrospective incidence and prevalence data ${ }^{22-35}$; three reported data from prospective case series of disease progression ${ }^{44-46}$; and eight reported data from retrospective case series. ${ }^{36-43}$ Only two studies stated how they defined FALS. ${ }^{30}{ }^{44}$ In total, 575 cases of FALS were recorded among 11221 reported cases of ALS.

The type of study, rate of FALS, source of case ascertainment and case inclusion criteria are outlined in table $1 .{ }^{13-46}$

\section{Meta-analysis}

Pooled analysis of all studies generated a rate of FALS of $4.6 \%$ (95\% CI 3.9\% to $5.5 \%$ ) (table 2 ).

A degree of heterogeneity was noted between reported rates of FALS in the prospective population based registers available for analysis. ${ }^{13-21}$ The pooled result for rate of FALS for these studies was $5.1 \%(95 \%$ CI $4.1 \%$ to $6.1 \%)$.

In the 14 retrospective population based studies, the pooled result for rate of FALS was $3.7 \%(95 \% \text { CI } 2.9 \% \text { to } 4.7 \%)^{22-36}$

Figure 1 demonstrates a Forrest plot of the results.

The individual rate of FALS for each country in Europe was plotted on a map to determine a possible geographic pattern (figure 2).

Regions of relatively homogenous genetic origin, such as Ireland and Scotland (both of which both have large prospective databases of over 1200 patients) exhibit almost the same rate of FALS. Lower rates are reported in the more diverse populations of southern Italy and the Balkan Peninsula. Variations in the distribution of families with SOD1 mutations have also been identified. The population based rate of SOD1 mutations in Italian FALS patients is $13 \%$, and the rate in sporadic ALS in $0.7 \%{ }^{11}$ This contrasts sharply with rates of $1.9 \%$ in a Dutch FALS group and $0.44 \%$ in Dutch sporadic ALS patients. ${ }^{67}$ The true population based rate of SOD1 gene mutations in other countries remains unclear, as the majority of studies performed to date have been neither prospective nor population based. Moreover, we were unable to identify a geographic correlation between FALS rates and reported SOD1 mutation rates for the same region.

\section{DISCUSSION}

Our analysis indicates that the commonly accepted frequency of $10 \%$ for FALS represents an overestimation of the dominantly inherited Mendelian form of ALS. The population based frequency of $5.1 \%$ is likely to represent the most accurate estimation of rate of FALS, as population based studies include all patients in a defined geographic area in a given period of time. Accordingly, reported rates of FALS of $10 \%$ from previous studies are likely to have been biased by ascertainment from populations enriched by FALS cases.

Geographic variation in the rate of FALS in Europe (figure 2) may reflect true population based differences across different regions. Heterogeneity in the genetic substructure of European populations has been demonstrated recently. ${ }^{68}$ These geographic differences may occur because of variability in the underlying genetic structure of the European population. However, difficulties in case ascertainment could also account for this difference. Evidence for population based differences is emerging for SOD1: a founder effect for the A4V mutations in SOD1 has been recently identified in the USA ${ }^{69}$ and this mutation is rare in Europe. Mutations in OPTN seem to be primarily in Japanese populations. ${ }^{70}$ The existence of geographic variability for TARDP and FUS has not yet been established. As more causative genes are identified in FALS, detailed analysis of the frequency of various mutations within individual FALS populations will become available.

The meta-analysis is limited by the absence of a clear definition of FALS. While most groups define FALS as the presence of ALS in at least two members of an extended kindred, the degree or relatedness and the size of the extended kindred are rarely considered. Given that the lifetime risk of ALS is 1:450 for women and 1:350 for men, ${ }^{54}{ }^{54 a}$ there is an increasing probability of two affected members with sporadic ALS occurring in the same kindred as the size of the kindred increases. Therefore, ensuring segregation of mutations within kindreds is also

Table 2 Meta-analysis results: subgroup analysis and pooled analysis

\begin{tabular}{|c|c|c|c|c|c|c|}
\hline \multirow[b]{2}{*}{ Study type } & \multicolumn{6}{|c|}{ Proportion FALS cases $(95 \% \mathrm{CI})$} \\
\hline & No of studies & FALS cases & Total ALS cases & Fixed effects & Random effects & $I^{2}$ \\
\hline $\begin{array}{l}\text { Group 1: prospective population based } \\
\text { registry }\end{array}$ & 8 & 265 & 5283 & $5.0 \%(4.4$ to 5.6$)$ & $5.1 \%(4.1$ to 6.1$)$ & $56 \%$ \\
\hline $\begin{array}{l}\text { Group 2: retrospective population based } \\
\text { study }\end{array}$ & 14 & 59 & 1666 & $3.7 \%(2.9$ to 4.7$)$ & $3.7 \%(2.9$ to 4.7$)$ & $0 \%$ \\
\hline Group 3: prospective case series & 3 & 151 & 2035 & $7.3 \%(6.2$ to 8.4$)$ & $5.7 \%(2.5$ to 9.9$)$ & $91 \%$ \\
\hline Group 4: retrospective case series & 8 & 100 & 2237 & $4.4 \%$ (3.6 to 5.2 ) & $4.8 \%(3.1$ to 6.8$)$ & $74 \%$ \\
\hline Pooled results for all studies (groups 1-4) & $\underline{33}$ & $\underline{575}$ & 11,221 & $5.1 \%(4.7$ to 5.5$)$ & $4.6 \%(3.9$ to 5.5$)$ & $69 \%$ \\
\hline
\end{tabular}

FALS, familial amyotrophic lateral sclerosis. 


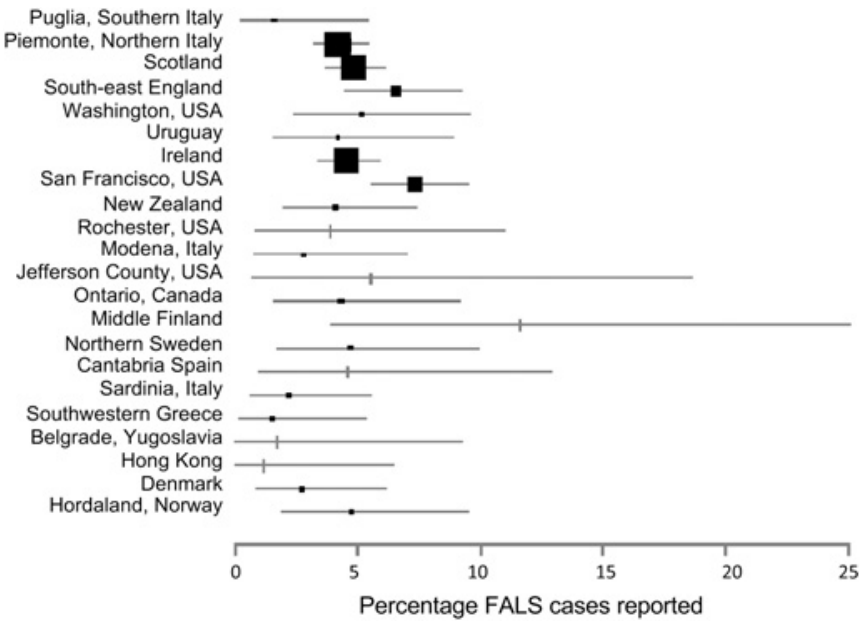

Figure 1 Forrest plot of population based prospective and retrospective studies included in pooled analysis yielding a FALS rate of $4.5 \%$ (95\% Cl 3.8 to 5.3). FALS, familial amyotrophic lateral sclerosis.

important, as exemplified by a recent report of two apparent SOD1 kindreds in which the disease did not segregate with a known pathogenic SOD1 mutations. ${ }^{71}$

In conclusion, we have demonstrated that the rate of FALS across population based studies rarely exceeds $5 \%$ of all cases of ALS. This contrasts with the generally accepted figure of $10 \%$, which originates from a paper written in $1955^{2}$

Careful prospective population based analysis of kindreds using validated criteria for a diagnosis of FALS is required to confirm that $5 \%$ represents the true population based rate of familial ALS, and to determine whether the documented geographic variation in rates of FALS is corroborated.

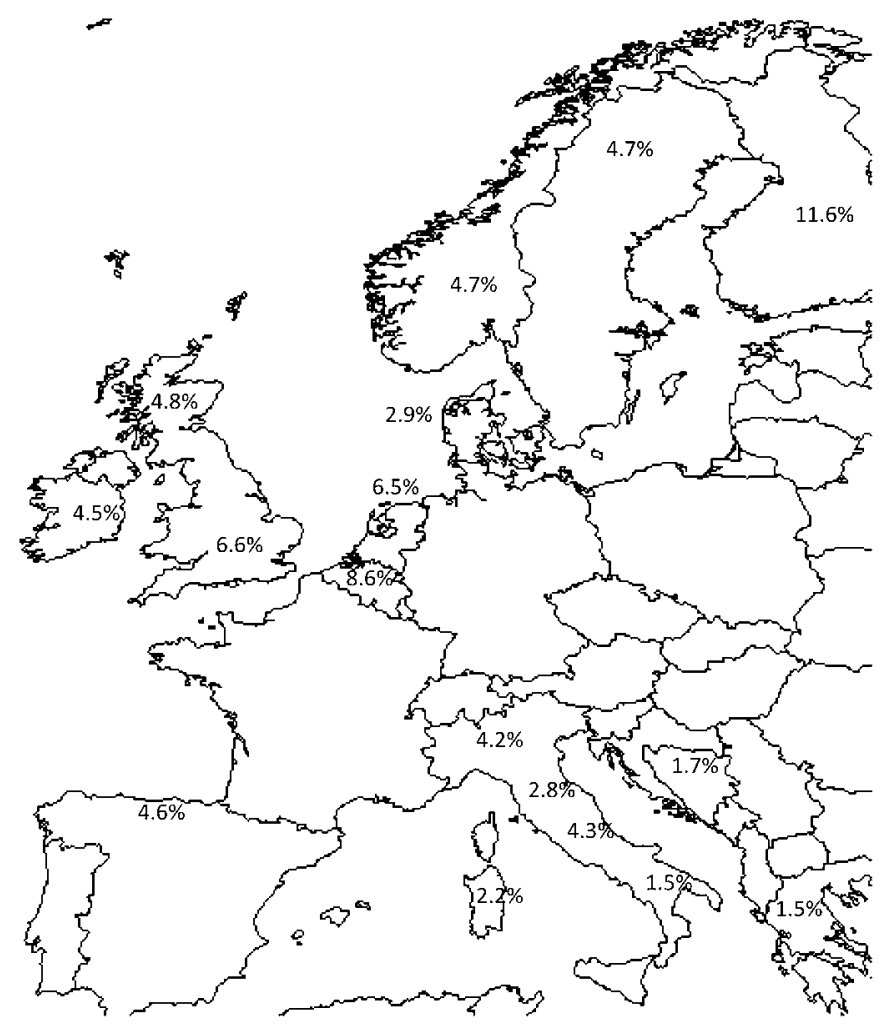

Figure 2 Rate of familial amyotrophic lateral sclerosis in individual European countries.
Funding This work was supported by the IMNDA, IMNDRF and HRB funding.

Competing interests $\mathrm{OH}$ is a HRB Clinician Scientist. Her group has received unrestricted research grants from Merck Serono, Biogen Idec and Bayer Schering. She has received honoraria for providing expert advice to Merck Serono, Biogen Idec, Janssen Cilag, Allergan, Ono Pharmaceuticals and CytRx.

Provenance and peer review Not commissioned; externally peer reviewed.

\section{REFERENCES}

1. Wechsler IS, Sapirstein MR, Stein A. Primary and symptomatic amyotrophic latera sclerosis: a clinical study of 81 cases. Am J Med Sci 1944;208:70.

2. Kurland L, Mulder D. Epidemiologic investigations of amyotrophic lateral sclerosis. familial aggregation indicative of dominant inheritance Part I. Neurology 1955;5:182-96.

3. Fang $\mathbf{F}$, Kamel $F$, Lichtenstein $P$, et al. Familial aggregation of amyotrophic lateral sclerosis. Ann Neurol 2009;66:94-9.

4. Brown R. Amyotrophic lateral sclerosis-insights from genetics. Arch Neurol 1997; 54:1246-50.

5. Valdmanis $\mathbf{P}$, Rouleau G. Genetics of familial amyotrophic lateral sclerosis. Neurology 2008;70:144-52.

6. Majoor-Krakauer D, Willems PJ, Hofman A. Genetic epidemiology of amyotrophic lateral sclerosis. Clin Genet 2003;63:83-101.

7. Shaw PJ. Genetic inroads in familial ALS. Nat Genet 2003;29:103-4.

8. Andersen PM, Borasio GD, Dengler R, et al. Good practice in the management of amyotrophic lateral sclerosis: clinical guidelines. An evidence-based review with good practice points. EALSC Working Group. Amyotroph Lateral Scler 2007; 8:195-213

9. Andersen PM, Nilsson P, Keränen ML, et al. Phenotypic heterogeneity in motor neuron disease patients with CuZn-superoxide dismutase mutations in Scandinavia. Brain 1997:120:1723-37.

10. Eisen A, Mezei M, Stewart $H$, et al. SOD1 gene mutations in ALS patients from British Columbia, Canada: Clinical features, neurophysiology and ethical issues in management. Amyotroph Lateral Scler 2008;9:108-19.

11. Chio A, Traynor BJ, Lombardo F, et al. Prevalence of SOD1 mutations in the Italian ALS population. Neurology 2008;70:533-7.

12. Orwell RW, Habgood JJ, Malaspina A, et al. Clinical characteristics of SOD1 gene mutation in UK families with ALS. J Neurol Sci 1999;169:56-60.

13. Logroscino G, Beghi E, Zoccolella $\mathrm{S}$, et al. Incidence of amyotrophic lateral sclerosis in southern Italy: a population based study. J Neurol Neurosurg Psychiatry 2005;76:1094-8.

14. Chiò A, Mora G, Calvo A, et al. Epidemiology of ALS in Italy. A 10-year prospective population-based study. Neurology 2009;72:725-31.

15. Forbes R, Colville S, Parratt J, et al. The incidence of motor neuron disease in Scotland. J Neurol 2007;254:866-9.

16. Abhinav K, Stanton B, Johnston C, et al. Amyotrophic lateral sclerosis in South-Eas England: a population-based study. The South-East England register for amyotrophic lateral sclerosis (SEALS Registry). Neuroepidemiology 2007;29:44-8.

17. McGuire V, Longstreth WT, Koepsell T, et al. Incidence of amyotrophic lateral sclerosis in three counties in western Washington State. Neurology 1996;47:571-3.

18. del Aguila MA, Longstreth WT, Koepsell T, et al. Prognosis in amyotrophic latera sclerosis: a population-based study. Neurology 2003;60:813-19.

19. Cruz DC, Nelson LM, McGuire V, et al. Physical trauma and family history of neurodegenerative diseases in amyotrophic lateral sclerosis: a population-based case-control study. Neuroepidemiology 1999;18:101-10.

20. Vzquez MC, Ketzoian C, Legnani C, et al. Incidence and prevalence of amyotrophic lateral sclerosis in Uruguay: a population-based study. Neuroepidemiology 2008;30:105-11.

21. Norris F, Shepherd R, Denys E, et al. Onset, natural history and outcome in idiopathic adult motor neuron disease. J Neurol Sci 1993;118:48-55.

22. Murphy M, Quinn S, Young J, et al. Increasing incidence of ALS in Canterbury, New Zealand: A 22-year study. Neurology 2008;11:1889-95.

23. Sorenson EJ, Stalker AP, Kurland L, et al. Amyotrophic lateral sclerosis in Olmsted County, Minnesota, 1925 to 1998. Neurology 2002:59:280-2.

24. Mandrioli J, Faglioni P, Merelli E, et al. The epidemiology of ALS in Modena, Italy Neurology 2003;60:683-9.

25. Turabelidze G, Zhu BP, Schootman M, et al. An epidemiologic investigation of amyotrophic lateral sclerosis in Jefferson County, Missouri, 1998-2002. Neurotoxicology 2008;29:81-6.

26. Hudson AJ, Davenport A, Hader WJ. The incidence of amyotrophic lateral sclerosis in southwestern Ontario, Canada. Neurology 1986;36:1524.

27. Murros K, Fogelholm R. Amyotrophic lateral sclerosis in Middle-Finland: an epidemiological study. Acta Neurol Scand 1983;67:41-7.

28. Forsgren L, Almay B, Holmgren G, et al. Epidemilogy of motor neuron disease in northern Sweden. Acta Neurol Scand 1983:68:20-9.

29. Lopez-Vega JM, Calleja J, Combarros 0, et al. Motor neuron disease in Cantabria Acta Neurol Scand 1988;77:1-5.

30. Giaggheddu M, Puggioni G, Masala C, et al. Epidemiologic study of amyotrophic lateral sclerosis in Sardinia, Italy. Acta Neurol Scand 1983;68:394-404.

31. Argyriou AA, Polychronopoulos P, Papapetropoulos S, et al. Clinical and epidemiological features of motor neuron disease in south-western Greece. Acta Neurol Scand 2005;111:108-13. 
32. Alcaz S, Jarwbincki M, Pekmezovic T, et al. Epidemiological and clinical characteristics of ALS in Belgrade, Yugoslavia. Acta Neurol Scand 1996;94:264-8.

33. Fong KY, Yu YL, Chan YW, et al. Motor neuron disease in Hong Kong Chinese: epidemiology and clinical picture. Neuroepidemiology 1996;15:239-45.

34. Hojer-Pedersen E, Christensen PB, Jensen NB. Incidence of prevalence of moto neuron disease in two Danish counties. Neuroepidemiology 1989;8:151-9.

35. Tysnes $\mathbf{0 B}$, Vollset SE, Aarli JA. Epidemiology of amyotrophic lateral sclerosis in Hordaland county, western Norway. Acta Neurol Scand 1991;83:280-5.

36. Werneck LC, Bezerra R, Silveira 0, et al. A clinical epidemiological study of 251 cases of amyotrophic lateral sclerosis in the south of Brazil. Arq Neuropsiquiatr 2007:65:189-95.

37. Li TM, Alberman E, Swash M. Comparison of sporadic and familial disease amongst 580 cases of motor neuron disease. J Neurol Neurosurg Psychiatry 1988;51:778-84.

38. Kurland L, Mulder D. Epidemiologic investigations of amyotrophic lateral sclerosis Familial aggregation indicative of dominant inheritance part II. Neurology 1955;5:249-68

39. Sabatelli M, Madia F, Conte A, et al. Natural history of young-adult amyotrophic lateral sclerosis. Neurology 2008;71:876-81.

40. Murray TJ, Pride S, Haley G. Motor neuron disease in Novia Scotia. Can Med Assoc J 1974:110:814-17.

41. Thjis V, Peeters E, Theys $\mathrm{P}$, et al. Demographic characteristics and prognosis in a Flemish amyotrophic lateral sclerosis population. Acta Neurol Belg 2000:100:84-90.

42. Gubbay S, Kahana E, Zilber N, et al. Amyotrophic lateral sclerosis. A study of its presentation and prognosis. J Neurol 1985;232:295-300.

43. Louwerse ES, Visser CE, Bossuyt PM, et al. Amyotrophic lateral sclerosis: mortality risk during the course of the disease and prognostic factors. J Neurol Sci 1997:152(Suppl 1):10-17.

44. Haverkamp LJ, Appel V, Appel SH. Natural history of amyotrophic lateral sclerosis in a database population: Validation of a scoring system and a model for survival prediction. Brain 1995:3:118.

45. Rosen A. Amyotrophic lateral sclerosis: clinical features and prognosis. Arch Neurol 1978;35:638-42.

46. Ringel SP, Murphy JR, Alderson MK, et al. The natural history of amyotrophic lateral sclerosis. Neurology 1993;43:1316-21.

47. Fang $\mathbf{F}$, Valdimarsdottir U, Bellocco R, et al. Amyotrophic lateral sclerosis in Sweden, 1991-2005. Arch Neurol 2009;66:515-19.

48. Marin B, Gil J, Preux PM, et al. Incidence of amyotrophic lateral sclerosis in the Limousin region of France, 1997-2007. Amyotroph Lateral Scler 2009:10:216-20.

49. Beghi E, Millil A, Micheli A, et al. Incidence of ALS in Lombardy, Italy. Neurology 2007:68:141-5.

50. Zaldivar T, Gutierrez J, Lara G, et al. Reduced frequency of ALS in an ethnically mixed population: A population-based mortality study. Neurology 2009;72:1640-5.

51. Fong GC, Cheng TS, Lam K, et al. An epidemiological study of motor neuron disease in Hong Kong. Amyotroph Lateral Scler Other Motor Neuron Disord 2005;6:164-8.

52. Gil J, Vazquez MC, Ketzoian C, et al. Prognosis of ALS: Comparing data from the Limousin referral centre, France, and a Uruguayan population. Amyotroph Lateral Scler 2009;10:355-60.
53. Nalini A, Thennarasu K, Gourie-Devi M, et al. Clinical characteristics and survival pattern of 1153 patients with amyotrophic lateral sclerosis: Experience over 30 years from India. J Neurol Sci 2008;272:60-70.

54. Alonso A, Logroscino G, Jick SS, et al. Incidence and lifetime risk of motor neuron disease in the United Kingdom: a population-based study. Eur $J$ Neurol 2009:16:745-51.

54a. Johnston CA, Stanton BR, Turner MR, et al. Amyotrophic lateral sclerosis in an urban setting. A population based study of inner city London. J Neurol 2006:252:1642-3

55. Kahana E, Alter M, Feldman M. Amyotrophic lateral sclerosis-a population Study. J Neurol 1976;212:205-13.

56. Okamoto K, Kobashi G, Washio M, et al. Descriptive epidemiology of amyotrophic lateral sclerosis in Japan, 1995-2001. J Epidemiol 2005;15:20-3.

57. Mulder DW, Kurland LT, Offord KP, et al. Familial motor neuron disease: amyotrophic lateral sclerosis. Neurology 1986;36:511-17.

58. Chiò A, Magnani C, Schiffer D. Amyotrophic lateral sclerosis mortality in Italy, 1958 to 1987. A cross-sectional and cohort study. Neurology 1993:43:927.

59. Matsumoto N, Worth R, Kurland L, et al. Epidemiologic study of ALS in Hawaii. Neurology 1972;22:934-40.

60. Juergens S, Kurland L, Okazaki H, et al. ALS in Rochester, Minnesota, 1925-1977. Neurology 1980;30:463

61. Neilson S, Gunnarsson LG, Robinson I, et al. Rising mortality in motor neuron disease in Sweden 1961-1990. Acta Neurol Scand 1994:90:150-9.

62. Giagheddu M, Mascia V, Cannas A, et al. Amyotrophic lateral sclerosis in Sardinia Italy; an epidemiological study. Acta Neurol Scand 1993;87:446-54.

63. O'Toole 0, Traynor BJ, Brennan P, et al. Epidemiology and clinical features of amyotrophic lateral sclerosis in Ireland between 1995 and 2004. J Neurol Neurosurg Psychiatry 2008:79:30-2.

64. Zoccolella S, Beghi E, Palagano G, et al. Signs and symptoms at diagnosis of amyotrophic lateral sclerosis: a population-based study in southern Italy. Eur J Neurol 2006;13:789-92.

65. The Scottish Motor Neuron Disease Research Group. The Scottish Motor Neuron Disease Register: a prospective study of adult onset motor neuron disease in Scotland. Methodology, demography and clinical features of incident cases in 1989 J Neurol Neurosurg Psychiatry 1992;55:536-41.

66. Kihira T, Yoshida S, Hironishi M, et al. Changes in the incidence of amyotrophic lateral sclerosis in Wakayama, Japan. Amyotroph Lateral Scler 2005;6:155-63.

67. van Es MA, Dahlberg C, Birve A, et al. Large scale SOD1 mutation screening provides evidence for genetic heterogeneity in amyotrophic lateral sclerosis. J Neurol Neurosurg Psychiatry 2010;81:562-6.

68. Novembre J, Johnson T, Bryc K, et al. Genes mirror geography within Europe. Nature 2008:456:98-101.

69. Saeed M, Yang Y, Deng H-X, et al. Age and founder effect of SOD1 A4V mutation causing ALS. Neurology 2009;72:1634-9.

70. Maruyama $\mathbf{~ H}$, Morino $\mathrm{H}$, Ito $\mathrm{H}$, et al. Mutations of optineurin in amyotrophic latera sclerosis. Nature 2010;465:223-6.

71. Rabe M, Felbecker A, Waibel S, et al. The epidemiology of CuZn-SOD mutations in Germany: a study of 217 families. J Neurol 2010;257:1298-302. 